\title{
EFFECTIVE INTERMITTENT ADMINISTRATION OF NABIXIMOLS IN A PATIENT WITH AUTISM (ASPERGER'S SYNDROME)
}

\author{
Horst J. Koch \\ Heinrich Braun Klinikum Zwickau, Dept. of Psychiatry and Psychotherapy, Zwickau, Germany \\ Contact: Horst Koch MD PhD DCPSA MFPM \\ Heinrich Braun Klinikum Zwickau \\ Karl-Keil-Straße 35 \\ 08060 Zwickau, \\ E-mail: horstjosef.k Germany och@t-online.de
}

A 46-year-old male patient suffering from Asperger's syndrome tried to improve autism including social isolation by means of intermit-tent doses of off-label nabixmols for five years. He confirmed drug abuse 18 years before and was clean in repeated drug tests in our outpatient clinic. He was able to initiate contacts, to complete training in informatics and went freelance as an IT expert. After cessation of nabiximols, his clin-ical state deteriorated again, including social decline. Although the case shows substantial improvement in autism by intermittent administration of nabiximols, further investigations are necessary to prove the principle. Acta Medica Medianae 2017;56(2):102-104.

Key words: Asperger's syndrome, Nabiximols, cannabinoid receptors, re-integration 